Tobago forest reserves now cover 279,996 acres, or 22 per cent of the country. To this about 65,000 acres of hill forest will be added when the surveys have been completed, bringing the total to 27 per cent. Adjustments are probable later, and it is assumed that the forest estate will eventually be about 300,000 acres - a very satisfactory area for the Islands. Of this area, 64,000 acres have been allocated to the plantation programme, mainly teak (an exotic, of course), and about 100,000 acres, parts of which have not yet been declared forest reserves, may be found to be inaccessible for a long period. Swamps cover a certain amount of area. Thus there are 128,000 acres of accessible forest to be regenerated under systems other than teak and mixed hardwood plantations. In the north a natural regeneration programme is in force over 31,800 acres, which will be treated under the shelter-wood system. In general, the forest management in the Islands may be considered to be in a satisfactory state.

\section{André Mayer Fellowships of the Food and Agri- culture Organization}

THE United Nations Food and Agriculture Organization has established a number of fellowships for advanced training in preparation for research work in topics of particular interest to member countries and to the Organization as a whole. Five or six fellowships are being offered this year, spread over the whole field covered by the Organization, namely, agriculture, agricultural economics and statistics, fisheries, forestry and nutrition. They will be called André Mayer fellowships in memory of the late André Mayer, who was closely associated with scientific research in France as well as international work, particularly in relation to the Organization. The awards will be for periods up to two years, with the possibility of an extension to a maximum of thirty months, and payment will be about 250 dollars a month. Further information can be obtained from the Secretariat of the F.A.O. National Committee for the United Kingdom, c/o Ministry of Agriculture, Fisheries and Food, 10 Whitehall Place, London, S.W.I.

\section{Scottish Postgraduate Scholarships in Agriculture}

THE Department of Agriculture for Scotland has awarded the following postgraduate scholarships in agricultural subjects, tenable for periods up to three years at the institution shown: Husbandry, R. C. Kirkwood (University College of Wales, Aberystwyth), A. McKechnie (University of Reading), and J. L. Beveridge, S. S. Fluss and C. G. M. Duncan (University of Cambridge) ; Engineering, D. A. Jack (King's College, Newcastle upon Tyne). The awards held by the following, all of which are in husbandry, are being continued for a further period: A. D. Drysdale (University of Minnesota), D. M. S. Livingston (University of Aberdeen), C. Smith (Iowa State College), R. A. N. Napier (University of Edinburgh), J. Frame, I. C. Beattie and W. C. Smith (Massey Agricultural College, New Zealand), and N. C. Lawson (Macdonald College, McGill University).

\section{Announcements}

Major C. W. Hume, director of the Universities Federation for Animal Welfare, which he founded originally in 1926 as the University of London Animal Welfare Society, has been awarded the Albert Schweitzer Medal of the American Animal Welfare Institute.
DR. R. Lessing has been elected president of the National Smoke Abatement Society in succession to Sir Ernest Smith.

THE following appointments in the University of London have been announced: Mr. P. V. Danckwerts, deputy director of research and development of the Industrial Group, Atomic Energy Authority, to the University chair of chemical engineering science tenable at the Imperial College of Science and Technology; Dr. H. Tropper, senior lecturer at Queen Mary College, to the University readership in electrical engineering tenable at that College.

DR. D. STARKIE, director of research at the Hosiery and Allied Trades Research Association, is relinquishing his appointment in order to join the Board of English Rose, Ltd., as director of research in charge of the newly created Department of Research. Dr. Starkie will head a team of experienced scientists and technologists and will be concerned with research on hose materials, machines and products.

THE sixth George Scott Robertson Memorial Lecture, given under the auspices of the Ministry of Agriculture, Northern Ireland, will be delivered in the Sir William Whitla Hall of The Queen's University, Belfast, at 3 p.m. on October 26 , by Dr. D. P. Cuthbertson, director of the Rowett Research Institute, Aberdeen. The subject will be "Animal Nutrition in relation to Production and Disease". The Lecture will be open to the public.

THE programme of lectures for 1956-57 of the Bedson Club, King's College, Newcastle upon Tyne, is as follows: October 26, modern inorganic stereochernistry, by Prof. R. S. Nyholm; November 16, the chemistry of some naturally occurring poly. acetylenes, by Prof. B. Lythgoe; and January 25, polymerization in heterogeneous systems, by Prof. C. E. H. Bawn.

THE first meeting of the British Society for Immunology will be held at the Wellcome Foundation, 183 Euston Rroad, London, - N.W.I, during November 9-10. Following introductory remarks by Sir Henry Dale, the meeting will consist of the reading of scientific papers, the afternoon of the first day being devoted to a symposium on "Complement". Further information can be obtained from Prof. G. Payling Wright, Department of Pathology, Guy's Hospital Medical School, London, S.E.1.

The Morcom Green, Edwards Prize, which is offered yearly through the New Zealand Institute of Chemistry for the encouragement of original research by younger chemists, has been awarded this year to I. R. C. McDonald, of the Dominion Laboratory, Department of Scientific and Industrial Research, New Zealand, for his work on methods for the analysis of insecticides used in agriculture. Mr. McDonald has been engaged in the analysis of complex organic mixtures, with particular emphasis upon wool fat, insecticidal mixtures and wood chemistry, and has developed original techniques, using a double-beam infra-red spectrophotometer, for determining accurately the proportions of the toxic substances present in insecticide formulations.

Erratum. In Nature of August 4, p. 240, it was stated that Dr. F. Körösy had been appointed professor of physical chemistry in the TechnionIsrael Institute of Technology, Haifa; he has, in fact, been appointed research fellow in physics at the Technion. 